\title{
Penerapan Model Pembelajaran Think Pair Share untuk Meningkatkan Aktivitas Belajar IPA Siswa Kelas IV SD
}

\author{
Yonarlianto Tembang ${ }^{1 *}$
}

${ }^{1}$ Jurusan Pendidikan Guru Sekolah Dasar, Universitas Musamus Merauke

\author{
A R T I C L E I N F O \\ Article history: \\ Received 20 Desember \\ 2017 \\ Received in revised form \\ 6 januari 2018 \\ Accepted 19 Januari 2018 \\ Available online 20 \\ Februari 2018
}

\section{Kata Kunci:}

Think Pair Share

Learning Activities

Learning Science

Keywords:

Think Pair Share

Aktivitas Belajar

Pembelajaran IPA

\begin{abstract}
A B S T R A K
Penelitian ini bertujuan untuk meningkatkan aktivitas belajar IPA siswa dengan penerapan model pembelajaran TPS. Penelitian ini adalah penelitian tindakan kelas jenis kolaboratif partisipatori yang dilaksanakan dengan dua siklus. Setiap siklusnya dilaksanakan sebanyak empat kali pertemuan, yang terdiri dari perencanaan, pelaksanaan, evaluasi dan refleksi. Subjek dalam penelitian ini adalah siswa kelas IV SD YPPK ST. Theresia Butiyang berjumlah 22 siswa yang terdiri dari 12 siswa laki-laki dan 10 siswa perempuan. Pengumpulan data diperoleh melalui wawancara, observasi dan tes. Bentuk analisis data yaitu deskriptif kualitatif. Hasil penelitian ini menunjukkan terjadi peningkatan disetiap siklusnya, berdasarkan observasi awal sebelum diterapkan model pembelajaran TPS nilai aktivitas belajar IPA siswa sebesar $45,06 \%$, meningkatkan $60,05 \%$ pada siklus 1 , dan pada siklus 2 meningkat menjadi $81,75 \%$, rata-rata peningkatan pada siklus 1 ke siklus 2 sebesar $21,70 \%$. Hasil penelitian ini menunjukan bahwa aktivitas belajar IPA siswa melalui penerapan model pembelajaran TPS dapat meningkat.
\end{abstract}

\section{A B S T R A C T}

This study aims to improve students' science learning activities with the application of TPS learning model. This research is a collaborative type collaborative class action research conducted with two cycles. Each cycle is held four meetings, consisting of planning, implementation, evaluation and reflection. Subjects in this study were fourth graders of SD YPPK ST. Theresia Butiyang numbered 22 students consisting of 12 male students and 10 female students. Data collection was obtained through interviews, observations and tests. Form of data analysis that is descriptive qualitative. The results of this study indicate an increase in each cycle, based on preliminary observations before the applied model of TPS learning value of science learning activities of students of $45.06 \%$, increase $60.05 \%$ in cycle 1, and in cycle 2 increased to $81.75 \%$ average increase in cycle 1 to cycle 2 of $21.70 \%$. The results of this study indicate that the learning activities of science students through the application of TPS learning model can increase.

\footnotetext{
1 Corresponding author.

E-mail addresses: yonartembang@unmus.ac.id(Yonarlianto Tembang),
} 


\section{Pendahuluan}

Proses pembelajaran merupakan kegiatan utama dalam pendidikan untuk memenuhi tujuan pendidikan nasional. Pendidikan diharapkan dapat meningkatkan kemampuan, mutu kehidupan serta menghasilkan manusia yang terdidik dan mampu mengembangkan kemampuan yang dimilikinya. Salah satu cara yang dapat ditempuh untuk mewujudkan suasana pendidikan yaitu dengan proses pembelajaran yang artinya bawa pendidikan akan tercapai apabilaseorang pendidik dapat menyajikan metode pembelajaran yang lebih menarik yang dapat diterima oleh peserta didik itu sendiri.Menurut (Pidarta, 2013). Guru yang profesional adalah guru yang berupaya membuat siswanya belajar atas dorongan diri sendiri untuk mengembangkan bakat, pribadi, dan potensi lainya secara optimal kearah positif. Peranan guru sangat penting dalam pelaksanaan proses pembelajaran. Guru tidak hanya sekedar sebagai pemberi ilmu tapi juga berusaha untuk membantu peserta didik dalam mengembangkan potensi yang sudah dimilikinya.

Pembelajaran merupakan suatu proses interaksi peserta didik dengan pendidik dari sumber belajar pada suatu lingkungan pembelajaran itu sendiri. Faktor yang cukup dominan menyebabkan rendahnya minat siswa terhadap suatu pelajaran adalah pelaksanaan pembelajaran (McGee dkk., 2001).Strategi dan metode pembelajaran kerap kali kurang dilakukan dengan optimal oleh guru. Kebanyakan guru memilih metode pembelajaran yang dianggap paling mudah dalam perencanaannya dan pelaksanaannya.(Depdiknas, 1999;Teriska,2005). Pemilihan strategi dan metode pembelajaran yang tidak sesuai dengan materi yang diajarkan mencerminkan rendahnya kemampuan guru dalam merencanakan dan menyiapkan pelaksanaan pembelajaran, untuk itu di butuhkan suatu metode pembelajaran yang dapat membuat siswa terlibat langsung pada pembelajaran tersebut. (Ardiyanti, 2016), mencapai suatu tujuan pembelajaran guru dituntun untuk menerapkan model pembelajaran yang dapat mengarahkan siswa untuk dapat meningkatkan aktivitas belajar sehingga kemampuan siswa untuk melakukan suatu kegiatan pembelajaran akan berjalan dengan baik.

Pada umumnya aktivitas belajar siswa dapat diasumsikan sebagai suatu proses psikomotirik, yaitu suatu tindakan keterampilan yang akan berkembang jika sering dilakukan dan akan berpengaruh pada kemampuan kognitif siswa untuk aktif didalam berpikir. Hubungan ini dapat saling berkaitan dengan struktur yang mapan dan dapat dieksperisikan dari berbagai pemikiran dengan segala macam cara. Akativas belajar merupakan segala kegiatan yang dilakukan dalam proses interaksi antara guru dan siswa atau siswa dengan siswa dalam mencapai tujuan belajar yang diharapkan (Hamalik, 2010). Aktivitas belajar siswa dapat berpengaruh terhadap keberhasilan pembelajaran, aktivitas belajar siswa merupakan hal yang sangat penting bagi siswa, karena memberikan kesempatan kepada siswa untuk bersentuhan dengan objek yang sedang dipelajari sehingga pengetahuan siswa yang diberikan menjadi suatu konstruksi pengetahuan yang akan mengarah pada proses belajar seperti bertanya, mengajukan pendapat, mengerjakan tugas, dan dapat menjawab pertanyaan dari guru.

Guru dapat menerapkan berbagai metode dan strategi pembelajaran untuk dapat mengaktifkan proses pembelajaran siswa dan guru harus bisa menciptakan situasi pembelajaran yang kondusif dan bermakna, yaitu pembelajaran yang dirancang agar siswa senang dan tidak merasa bosan dalam mengikuti pembelajaran. Berdasarkan hasil wawancara dengan guru kelas IV, mengatakan bahwa pembelajaran IPA yang dilakukan selama ini memang jarang menggunakan model pembelajaran, hanya menggunakan buku yang ada di sekolah dan lebih cenderung menggunakan metode konvesional sehingga pembelajaran ditandai dengan ketidakmampuan siswa untuk menghubungkan apa yang telah meraka telah pelajari dengan kehidupan sehari-hari. Ketika ditanya berkaitan dengan materi pelajaran IPA yang selama ini diajarkan guru menjawab bahwa selama ini guru hanya menggunakan buku paket yang ada di sekolah sebagai alternative didalam proses pembelajaran IPA tanpa memintah keterlibatan siswa secara langsung. Hal ini dibuktikan dengan dokumen hasil penilaian yang diberikan guru pada nilai UTS pada pelajaran IPA 60,00\% siswa yang belum mencapai KKM dari 22 siswa. dengan demikian sekitar 50\% siswa belum terlaksanadalam pembelajaran IPA pada kelas IV SD YPPK ST. Theresia Buti Merauke.

Berdasarkan permasalahan yang didapat melalui wawancara dan observasi serta melihat secara langsung nilai ril dari mata pelajaran IPA di SD YPPK ST. Theresia Buti Merauke. Terdapat masalah yang menghambat proses pembelajaran dan membutuhkan metode untuk menindak lanjuti masalah yang ada di kelas. Hal tersebut yang membuat siswa sangat sulit untuk memahami materi pelajaran IPA, karena dalam proses pembelajaran guru yang menjadi pusat perhatian dalam pembelajaran IPA. Berdasarkan permasalahan tersebut, perlu adanya upaya untuk menemukan sosuli dalam proses pembelajaran IPA dengan menerapakan pembelajaran yang berpusat pada siswa (student centered) yang dapat melibatkan siswa secara aktif dalam proses pembelajaran serta dapat meningkatkan hasil belajar siswa. Model pembelajaran kooperatif tipe TPSyang dapat memberikan kesempatan kepada siswa untuk belajar dengan temannya serta mampu meningkatkan kemampuan belajar mandiri siswa. TPS merupakan jenis 
pembelajaran kooperatif yang dirancang untuk membentuk diskusi yang dapat meningkatkan kemampuan berpikir siswa serta dan mendorong partisipasi siswa dalam kelas sehingga dapat menumbuhkan aktivitas belajar siswa untuk mengikuti pembelajaran (Azlina, 2010:23-24).

Model pembelajaran TPS merupakan strategi pembelajaran kooperatif yang mencakup tiga komponen inti yaitu waktu untuk berpikir, waktu untuk berbagai dengan pasangan dan waktu untuk berbagi di antara pasangan untuk kelompok yang lebih besar (Bamiro \& Ajayi, 2015). Penelitian ini bertujuan untuk mengetahui aktivitas belajar siswa melalui penerapan model pembelajaran TPS terhadap mata pelajaran IPA serta memperbaiki hasil belajar siswa sehingga mencapai nilai KKM.

\section{Metode Penelitian}

Penelitian ini merupakan penelitian tindakan kelas (PTK) jenis kolaboratif partisipatoris dimana peneliti bekerjasama dengan guru kelas, yang terdiri dari 2 siklus, setiap siklusnya dilaksanakan empat (4) kali pertemuan. Penelitian ini dilaksanakan pada bulan Februari - Maret tahun pelajaran 2017/2018 pada semester Dua. Subjek dalam penelitian ini adalah siswa kelas IV SD YPPK ST. Theresia Buti Merauke yang berjumalah 22 siswa. data dalam penelitian ini berupa lembar observasi aktivitas belajar IPA siswa yang diamati oleh observer disetiap siklusnya dan lebar hasil belajar siswa, berupa pertanyaan yang dipelajari setiap siklusnya.

Analisis data hasil lembar observasi keterlaksanaan pembelajaran dengan penerpan model pembelajaran TPS yang dilakukan oleh observeruntuk kegiatan pembelajaran siswa dihitung dengan menggunakan rumus sebagai berikut.

\section{Keterlaksanaan Pembelajaran $\frac{\text { Jumlah indikator yang terlaksanaa }}{\text { Jumlah skor maksimal indikator }}$ X $100 \%$}

Mengamati aktivitas belajar siswa selama tindakan digunakan lembar observasi dan dibantu juga oleh teman sejawat untuk mengamati proses pemebelajaran serta mengisi lembar observasi. Kategori yang diamati dalam observasi yaitu pada tahap think, pair, dan share. Adapun kriteria aktivitas belajar IPA siswa dapat dilihat pada tabel 1 .

Tabel 1. Kriteria Penilaian Aktivitas Belajar Siswa

\begin{tabular}{cc}
\hline Nilai $(\%)$ & Kriteria Keterlaksanaan \\
\hline $81-100$ & Sangat Baik \\
\hline $61-80$ & Baik \\
\hline $41-60$ & Sedang \\
\hline $21-40$ & Kurang \\
\hline $0-20$ & Sangat Kurang \\
\hline
\end{tabular}

(Riduwan, 2015)

Analisis untuk menghitung indikator keberhasilan aktivitas belajar IPA melalui lembar observasi keterlaksanaan model pembelajaran TPS jika menunjukka $\geq 80 \%$ dengan kriteria sangat baik dan baik maka penerapan model pembelajaran TPS dikatakan terlaksanaa dengan baik. Apabila hasil kriteria keterlaksanaan menunjukkan $<80 \%$ dengan kriteria sedang, kurang dan sangat kurang maka penerapan model pembelajaran TPS belum dikatakan terlaksanaa dengan baik dan dilanjutkan pada siklus berikutnya.

\section{Hasil dan Pembahasan}

Penelitian ini dilaksanakan di SD YPPK ST. Theresia Buti Merauke pada siswa kelas IV semester II tahun ajaran 2017/2018. Tindakan siklus I terdiri dari empat bagian pokok yang di adaptasi Kemmis dan Mc Taggart yaitu tahap perencanaan tindakan, pelaksanaan tindakan, observasi, dan refleksi.

\section{Paparan dan Implementasi Siklus I}

Kegiatan pelaksanaan tindakan siklus 1 dilaksanakan pada tanggal 06, 08 dan 09 Februari 2018. Secara garis besar pelaksanaan pembelajaran terdiri atas pendahuluan, kegiatan inti, dan penutup. Kegiatan pembelajaran diawali dengan materi perubahan kenampakan bumi tentang benda-benda langit, guru mengawali pembelajaran dengan memberikan apersepsi berupa pertanyaan kepada siswa berkaitan materi yang dibahas pada hari itu serta memberikan pertanyaan-pertanyaan kepada siswa pada tahap 
think, antusias, siswa mengikuti pembelajaran sudah mulai nampak dalam pembelajaran siswa menjawab pertanyaan yang diberikan oleh guru, dan pada tahap pair siswa mengerjakan LKS yang diberikan oleh siswa dengan berpasangan dengan kelompoknnya. Pada tahap share guru meminta siswa untuk menyampaikan hasil diskusi pasangannya di depan kelas dan kelompok lain menanggapi.

Berdasarkan lembar observasi keterlaksanaa aktivitas belajar IPA pembelajaran dapat dikatakan bahwa pertemuan pertama tidak semua tahap kegiatan pada tahap TPS dapat dicapai oleh siswa. Siswa dalam model pembelajaran TPS masih belum menyesuaikan dengan model pembelajaran, masih terdapat beberapa siswa yang kurang fokus dan tampak bingung dengan materi yang disampaikan oleh guru dan guru juga belum mampu mengatur waktu dengan baik sehingga alokasi waktu yang dibutuhkan melebihi waktu yang sudah ditetapkan pada RPP. Kegiatan pelaksanaan pada pertemuan kedua ini meliputi kegiatan apersepsi yang dilakukan dengan mereviu materi pertemuan pertama tentang benda-benda langit. Pada kegiatan pendahuluan siswa mengikuti pembelajaran sesuai dengan arahan guru,pada kegiatan inti siswa melihat percobaan yang dilakukan guru pada tahap think, siswa secara individu mengamati dan menganalisis percobaan yang dilakukan oleh guru. Kemudian siswa belajar dengan pasanganya pada tahap pair berbagai ide pemikiran dalam mengerjakan LKS yang diberikan oleh guru tentang percobaan yang dilakukan pada tahap think. Kemudian pada tahap share, siswa berdiskusi di dalam mempresentasikan hasil diskusi secara berpasangan tentang perubahan kenampakan bumi yang disebabkan oleh bulan beserta pengaruhnya terhadap gelombang air laut. Proses diskusi yang dilakukan berjalan dengan lancar, meskipun dalam pelaksanaanya siswa masih kurang aktif dalam berdiskusi. Pada kegiatan akhir guru memberikan penegasan tentang perubahan kenampakan bumi yang disebabkan oleh bulan. Berdasarkan lembar observasi keterlaksanaan pembelajaran, dapat dikatakan pada pertemuan kedua semua tahapan model pembelajaran think pair share telah dicapai dengan baik oleh guru.

Kegiatan pelaksanaan pada pertemuan ketiga, meliputi kegiatan apersepsi yang dilakukan oleh guru dengan memberikan reviu pada materi pertemuan sebelumnya tentang perubahan kenampakan bumi yang disebabkan oleh angin. Pada kegiatan inti, siswa mengamati gambar perubahan kenampakan bumi yang disebabkan oleh angin terjadi abrasi di pesisir pantai. Siswa diberikan kesempatan untuk mengemukkan pendapatnya terkait pada gambar yang diamati sesuai pada tahap think.Pada kegiatan inti guru meminta siswa untuk berpasangan pair meminta salah satu pasangan melakukan percobaan perubahan kenampakan bumi yang disebabkan oleh angin terjadinya abrasi pada pesisir pantai dengan alat yang disiapkan oleh guru dan dibantu oleh pengamat dalam hal ini observer. Siswa terlihat aktif dalam mengikuti pembelajaran maupun dalam kelompok, walaupun masih ada beberapa siswa yang masih kurang aktif. Kemudian pada tahap share siswa berdiskusi di depan kelas mempresentasikan hasil percobaan yang telah dilakukan bersama pasangannya tentang perubahan kenampakan bumi yang disebabkan oleh angina.

Pada kegiatan akhir, guru memberikan penegasan tentang perubahan kenampakan bumi yang disebabkan oleh angin. Siswa mengerjakan tes evaluasi siklus I berupa soal essay yang terdiri 8 butir soal. Siswa mengerjakan soal dengan sebaik-baiknya dan berjalan dengan tertib. Berdasarkan lembar observasi keterlaksanaan pembelajaran dengan model think pair share di peroleh data bahwa pada pertemuan ketiga semua tahapan kegiatan dapat dicapai oleh guru. Siswa yang kurang pasif jumlahnya sudah mulai berkurang dan siswa sudah mulai memahami materi yang telah dipelajari. Akan tetapi pada tahap share aktivitas siswa masih kurang percaya diri dalam menyampaikan pendapatnya dan masih malu-malu. Beberapa siswa terlihat masih belum fokus memperhatikan kelompok yang sedang presentasi dan banyak bermain.

Berdasarkan analisis siklus I melaui lembar observasi keterlaksanaan aktivitas siswa dan guru dengan penerapan model think pair share mencapai nilai sebesar $60,05 \%$ berada pada kategori baik, sedangkan analis data kentuntasan hasil belajar siswa secara klasikal belum mencapai kriteria belajar minimal yang telah ditentukan oleh peneliti, yaitu sebesar $\geq 80 \%$ dari jumlah keseluruhan siswa di kelas yang mencapai nilai KKM sebesar $65,08 \%$ atau dalam kategori sedang dan perlu perbaikan pada siklus berikutnya. Peneliti kembali melakukan refleksi bersama dengan guru kelas dan observeruntuk memperbaiki proses pembelajaran dikelas agar aktivitas belajar siswa dan hasil belajar siswa mencapai indikator yang telah ditetapkan.

\section{Paparan dan Implementasi Siklus II}

Pelaksanaan Kegiatan siklus II dilaksanakan pada tanggal 13, 14 dan 16 kegiatan yang dilakukan pada tahap perencanaan meliputi penyusunan RPP, menjelaskan tentang penyebab perubahan kenampakan bumi pengaruhnya terhadap daratan. Media yang digunakan dalam pembelajaran ini yaitu, materi pembelajaran, gambar-gambar yang sesuai dengna materi, lembar kerja siswa, dan lembar keterlaksanaan aktivitas model pembelajaran think pair share. Pada kegiatan awal guru melakukan apersepsi dengan memperlihatkan gambar-gambar lalu meminta siswa untuk memberikan pendapatnya 
mengenai kenampakan bumi pengaruhnya terhadap daratan. Selanjutnya guru membagikan LKS kepada siswa untuk dikerjakan sesuai pada tahap think, aktivitas siswa dalam mengerjakan LKS sangat bersemangat. Kemudian pada tahap pair siswa berpasangan untuk berbagi ide pemikiran terhadap masalah yang sudah dipikirkan secara individu pada tahap think. kegiatan pada tahap share siswa berdiskusi di kelas memprensentasikan hasil diskusi pasangannya tentang kenampakan bumi pengaruhnya terhadap daratan, ketika kegiatan presentasi siswa sudah mulai percaya diri dan semangat dalalm mempresentasikan hasil diskusi bersama pasangannya. Siswa terlihat fokus memperhatikan kelompok yang sedang melakukan presentasi, kelompok lain memberikan masukan dan pertanyaan terkait hasil diskusi yang dipresentasikan. Siswa tidak lagi malu dalam diskusi, saling memberikan saran dan mendengarkan kelompok lain berbicara serta cara bertanya siswa sudah mulai berubah dan lebih mendalami materi pelajaran. Guru telah melaksanakan semua tahapan yang teradapat dalam RPP dengan sangat baik. Namun melihat dari lembar evaluasi yang diberikan pada akhir pertemuan masih banyak siswa belum menjawab pertanyaan, ini diduga materi pembelajaran pada pertemuan ini sangat sulit dibandingkan pada pertemuan sebelumnya.

Kegiatan pada pertemuan kedua ini diawali dengan guru mereviukembali materi pertemuan sebelumnya tentang penyebab perubahan kenampakan bumi pengaruhnya terhadap daratan. Kemudian guru memotivasi siswa dengan menayangkan sebuah video, lalu meminta siswa untuk memberikan pendapatnya mengenai video tentang perubahan kenampakan bumi yang disebabkan oleh hujan, selanjutnya memberikan pemahaman akan video tersebut. Guru kemudian menugaskan siswa secara individu mengerjakan LKS yang diberikan pada tahap think dengan gagasan dan pandangan yang berbeda. Selanjutnya siswa bekerja secara berpasangan pair dengan mengamati percobaan yang dilakukan oleh pasangan lain didepan kelas tentang perubahan kenampakan bumi yang disebabkan oleh hujan, siswa sangat antusias mengikuti percobaan tersebut secara bergantian dan bersemangat mengerjakan LKS dan memberikan masukan dengan apa yang telah dikerjakan. Kegiatan share guru memintah siswa untuk mempresentasikan hasil kerjanya di depan kelas, semua siswa terlibat dalam presentasi tersebut tidak ada lagi siswa yang tidak memperhatikan kelompok yang sedang presentasi. Berdasarkan lembar observasi semua siswa sudah aktif dan sudah memahami materi yang dipelajari. Guru telah melaksanakan semua tahapan yang terdapat di dalam RPP dengan sangat baik, dan hasil belajar siswa lebih baik di banding pada pertemuan sebelumnya.

Pertemuan ketiga ini diawali dengan guru mereviu materi pada pertemuan kedua tentang perubahan kenampakan bumi yang disebabkan oleh hujan. Kemudian menyampaikan hal-hal yang akan dipelajari hari ini tentang perubahan kenampakan bumi yang disebabkan oleh gelombang air laut. Guru memutarkan video lalu meminta siswa untuk mengamati proses terjadi perubahan kenampakan bumi yang disebabkan oleh gelombang air laut. Kemudian guru membagikan LKS pada tahap think untuk dikerjakan secara individu. Kegiatan siswa dalam mengerjakan tugas pada tahap think nampak bersemangat dibuktikan dengan banyak siswa selesai mengerjakan soal pada tahap think, begitu pada tahap pair siswa bersama dengan pasangan kelompoknya saling bertukar pikiran untuk menjawab pertanyaan yang ada pada tahap pair. Semua siswa terlihat aktif dalam berdiskusi dan tidak ada lagi siswa yang menganggu temannya. Semua kegiatan pada model pembelajaran think pair share sudah dipahami oleh siswa dan guru. Berdasarkan lembar observasi keterlaksanaan model pembelajaran think pair share sudah dalam kategori sangat baik.

Berdasarkan analisis siklus II melaui lembar observasi keterlaksanaan aktivitas siswa dan guru dengan penerapan model think pair share terjadi peningkatan pada siklusnya, nilai yang di peroleh pada siklus II sebesar $81,75 \% \%$ berada pada kategori sangat baik, sedangkan untuk analisis data ketuntasan belajar siswa mengalami peningkatan pada siklus II sebesar 85,70 rata-rata peningkatan dari siklus I ke siklus II sebesar 20,62\%. Hasil lembar observasi keterlaksanaan aktivitas siswa dan guru dengan penerapan model think pair share tercantum dalam diagram berikut:

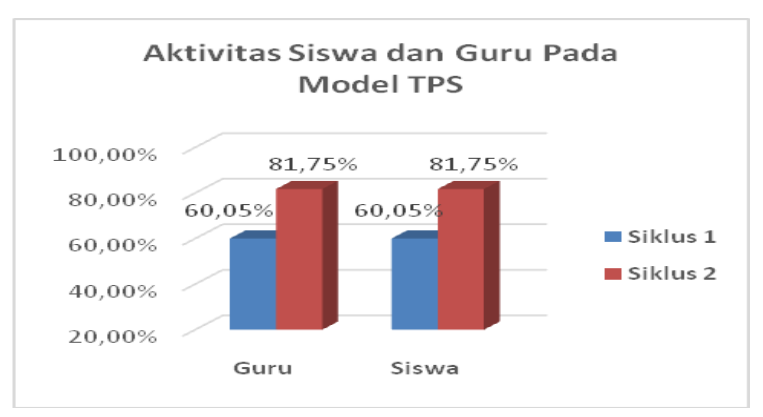

Diagram 1. Aktivitas Siswa dan Guru Pada Model TPS 
Diagram diatas menunjukkan bahwa lembar aktivitas siswa dan guru dengan menerapkan model think pair share dapat meningkatkan aktivitas belajar siswa serta meningkatkan hasil belajar siswa pada mata pelajaran IPA, karena pada setiap pertemuan guru melakukan reviu materi pembelajaran untuk mengetahui pemahaman siswa pada materi sebelumnya serta melaksanakan refleksi di akhir siklus dengan baik. Selama tindakan proses pembelajaran selalu mengalami perbaikan siswa aktif dalam belajar, mengembangkan kemampuannya untuk berpikir, berinteraksi dengan teman kelompoknya dan mampu menyampaikan pendapatnya di depan kelas tanpa ragu-ragu akan salah.

Penelitian ini sesuai dengan penelitian yang dilakukan oleh A. Ni'mah, dkk (2014) yang menyimpulkan bahwa model pembelajaran think pair share dapat meningkatkan aktivitas belajar siswa yang dapat dibuktikan dengan siswa mampu melakukan percobaan, mengajukan pertanyaan, mendengarkan presentasi kelompok dan mengemukkan pendapat serta mengerjakan LKS.

\section{Simpulan dan Saran}

Berdasarkan hasil penelitian dan pembahasan yang telah diuraikan, menunjukkan bahwa model pembelajaran think pair share dapat meningkatkan aktivitas belajar siswa dan hasil belajar siswa kelas IV SD YPPK. ST. Theresia Buti Merauke, hal ini dibuktikan dengan terjadinya peningkatkan dari siklus I ke siklus II. Siswa sangat antuasias mengikuti pembelajaran IPA yang ditunjukan dengan beberapa proses pembelajaran seperti, siswa tidak bosan mengikuti pembelajaran, aktif bertanya dalam kelompok maupun individu, mengemukkan pendapatnya, percaya diri, saling menghargai pendapat orang lain, dan bertanggung jawab dengan tugas yang diberikan baik itu individu maupun kelompok. Saran yang diberikan yaitu, pertama dalam proses pembelajaran hendaknya guru menerapakan model pembelajaran kreatif, inovatif dan afektif sehingga dapat meningkatkan aktivitas belajar siswa dengan sedirinya dapat meningkatkan hasil belajar IPA, kedua model pembelajaran think pair sharedapat dijadikan referensi sebagai model pembelajaran untuk mata pelajaran lain disertai dengan media yang menarik.

\section{Daftar Rujukan}

A. Nimah., P. Dwijananti. 2014. Penerapan Model Pembelajaran Think Pair Share (TPS) dengan Metode Eksperimen untuk Meningkatkan Hasil Belajar dan Aktivitas Belajar Siswa Kelas VIII Mts. Nahdlatul Muslimin Kudus. Journal.unnes.ac.id/sju/index.php/upej Vol: 3 No:2.

Ardiyanti, Yusi. 2016. Berpikir Kritis Siswa Dalam Pembelajaran Berbasis Masalah Berbantuan Kunci Determinasi. Jurnal Pendidikan Indonesia, Universitas Pendidikan Ganesha, Vol. 5, No.2, Oktober 2016 ISSN: 2303-288X.

Azlina, N. A. N. 2010. Cetls Supporting Collaborative Activities Among Students and Teschers Through The Use of Think-Pair-Share Techniques. IJCSI Internasional Journal of Computer Science Issues. Vol: 7

Bamiro, O.A., Ajayi, A.O. 2015. Effects of Guided Discovery and Think-Pair-Share Strategies on Secondary School Students' Achievement in Chemistry. SAGE Journals. http://sgo.sageup.com/content/5/1/2158244014562388,

Hamalik, Oemar. 2010. Kurikulum dan Pembelajaran. Jakarta: Bumi Aksara

Jasdilla. 2017. Hasil Belajar dan Pembelajaran Kooperatif Tipe TPS. Jurnal Pendidikan Indonesia Vol. 6, No.1, April 2017

Kemmis, S \& Mc Taggart, R. 1992. The Action Research Planner. Australia: Deakin University Press.

Mc.Gee, S., Corris, D. \& Shia R. 2001. Using Simalation to Improve Cognitive Reasoning. Proposal to AERA. SIG: Advanced Learning Technologis.

Pidarta, Made. 2013. Landasan Kependidikan: Stimulus Ilmu Pendidikan Bercorak Indonesia. Jakarta: Rineka Cipta

Riduwan, 2015. Skala Pengukuran Variabel-variabel Penelitian. Bandung: Alfabeta.

Teriska, R.2005. Peran LPMP dalam perberdayaan Guru Sains: Sebuah Upaya untuk Menyelesaikan Permasalahan Guru Sains di Jawa Barat. Makalah dipresentasikan dalam Seminar Himpunan Sarjana dan Pemerihati Pendidikan IPA Indonesia (HIS-PPIPAI III), Bandung, 22-23 Juli 2005. 